\title{
Simultaneous spectrophotometric determination of losartan potassium, amlodipine besilate and hydrochlorothiazide in pharmaceuticals by chemometric methods
}

\author{
D. NAGAVALLI ${ }^{1, *}$ \\ V. VAIDHYALINGAM ${ }^{2}$ \\ A. SANTHA ${ }^{3}$ \\ A. S. K. SANKAR ${ }^{1}$ \\ O. DIVYA ${ }^{4}$ \\ ${ }^{1}$ Department of Pharmaceutical \\ Analysis, Adhiparasakthi College \\ of Pharmacy, Melmaruvathur-603319 \\ Kanchipuram District, Tamil Nadu \\ India \\ ${ }^{2}$ Madras Medical College \\ Chennai-600003, India \\ ${ }^{3}$ C. L. Baid Metha College of Pharmacy \\ Chennai-600096, Tamil Nadu, India \\ ${ }^{4}$ IIT, Chennai-600036, Tamil Nadu \\ India
}

Accepted February 16, 2010

\begin{abstract}
In the present work, four different spectrophotometric methods for simultaneous estimation of losartan potassium, amlodipine besilate and hydrochlorothiazide in raw materials and in formulations are described. Overlapped data was quantitatively resolved by using chemometric methods, classical least squares (CLS), multiple linear regression (MLR), principal component regression (PCR) and partial least squares (PLS). Calibrations were constructed using the absorption data matrix corresponding to the concentration data matrix, with measurements in the range of $230.5-350.4 \mathrm{~nm}(\Delta \lambda=0.1 \mathrm{~nm})$ in their zero order spectra. The linearity range was found to be $8-40,1-5$ and 3-15 $\mu \mathrm{g} \mathrm{mL}^{-1}$ for losartan potassium, amlodipine besilate and hydrochlorothiazide, respectively. The validity of the proposed methods was successfully assessed for analyses of drugs in the various prepared physical mixtures and in tablet formulations.
\end{abstract}

Keywords: losartan potassium, amlodipine besilate, hydrochlorothiazide, spectrophotometry, chemometry

Losartan potassium (LOS), amlodipine besilate (AML) and hydrochlorothiazide (HYD) are drugs widely used for the treatment of hypertension and cardiovascular diseases in combined pharmaceutical preparations. Losartan potassium and its principal active metabolites block the vasoconstrictor and aldosterone-secreting effects of angiotensin II by selectively blocking the binding of angiotensin II to angiotensin II receptor type $1\left(\mathrm{AT}_{1}\right)$ receptor found in many tissues (vascular smooth muscle, adrenal gland). Amlodipine besilate inhibits the movement of calcium ions across the cell membrane into vascular smooth muscles and myocytes. Action is stronger in arterial resistance vessels causing peripheral vasodilatation and reduction in afterload. Hydrochlorothiazide inhibits the reabsorption of sodium and chloride at the beginning of the distal convo-

\footnotetext{
*Correspondence; e-mail: d_nagavalli@yahoo.co.in
} 
luted tubule. It causes natriuretic effect mainly by decreasing sodium and chloride reabsorption in the cortical segment of the ascending limb of the loop of Henley by inhibition of a specific $\mathrm{Na}^{+}, \mathrm{Cl}^{-}$co-transporter (1).

A few estimations in body fluids, in bulk in combination with other drugs and in single dosage forms have been reported for losartan potassium, amlodipine besilate and hydrochlorothiazide such as HPLC (2-7), spectrophotometry (8), multivariate approach (9), multi-syringe chromatography (MSC) (10) and $\operatorname{HPTLC}(11,12)$, ultra performance liquid chromatography (UPLC-MS) (13). All these drugs are available in combined tablet dosage forms, as antihypertensive agents. An extensive literature survey revealed that a number of methods are reported for the individual drugs but there is no report on simultaneous estimation of such a combination in physical mixtures or in pharmaceutical formulations by chemometric methods. The present article discusses the attempts made to develop simple, sensitive and reproducible methods for simultaneous estimation of these drugs in dosage forms.

Chemometric calibration techniques in spectral analysis are widely used in the quality control of drugs in mixtures and pharmaceutical formulations containing two or more drugs with overlapping spectra where separation procedures are not required in drug determination. We have also used these techniques for simultaneous analyses of mixtures (14-19).

In this study, four chemometric methods for spectral data processing are proposed for simultaneous determination of LOS, AML and HYD in their ternary mixtures and in tablets.

\section{EXPERIMENTAL}

\section{Instrument and software}

A Shimadzu (Japan) 2550-double beam spectrophotometer was used for all spectrophotometric measurements. Absorption spectra of the reference and test solutions were taken in 1-cm matched quartz cells over the range of 200-400 nm. Chemometric calculations on the resulting data were carried out with the PLS toolbox (Demover5.0) in MATLAB 7 (Math works).

\section{Samples and solvents}

Losartan potassium, amlodipine besilate and hydrochlorothiazide were kindly supplied by ATOZ India Ltd., India, and were certified to be 99.8 , 99.6 and $99.9 \%$ pure, respectively. The drugs were used without further purification. All the solvents used in spectrophotometric analysis were of analytical reagent grade. Trilopace tablets, batch number BF 70002 (Akums Drugs \& Pharmaceuticals Ltd., India), which were claimed to contain $50 \mathrm{mg}$ of losartan potassium USP, $5 \mathrm{mg}$ of amlodipine besilate BP and $12.5 \mathrm{mg}$ of hydrochlorothiazide IP, were used. 
D. Nagavalli et al.: Simultaneous spectrophotometric determination of losartan potassium, amlodipine besilate and hydrochlorothiazide in pharmaceuticals by chemometric methods, Acta Pharm. 60 (2010) 141-152.

\section{Standard solutions and mixtures}

Stock solutions of LOS (1 mg mL $\left.\mathrm{m}^{-1}\right)$, AML $\left(1 \mathrm{mg} \mathrm{mL}^{-1}\right)$ and HYD $\left(2 \mathrm{mg} \mathrm{mL}^{-1}\right)$ in methanol were diluted with water to prepare the working solutions $\left(0.16 \mathrm{mg} \mathrm{mL}^{-1}, 0.02\right.$ $\mathrm{mg} \mathrm{mL}^{-1}$ and $0.06 \mathrm{mg} \mathrm{mL}^{-1}$, respectively). The calibration set contained 25 and the prediction set 9 mixtures of calibration samples, so that the concentration of each drug in the resulting solutions was in its own linear dynamic range, as shown in Table 1. Furthermore, we demonstrated that in formulations LOS, AML and HYD range 1: 2.5: 10.

\section{Tablet analysis}

Twenty tablets were weighed accurately and powdered. An amount of the powder equivalent to $50 \mathrm{mg}$ of AML, $125 \mathrm{mg}$ of HYD and $500 \mathrm{mg}$ of LOS was dissolved in $50 \mathrm{~mL}$ of methanol. The solution was ultrasonicated for 10 minutes. Then, the solution was filtered through Whatman filter paper No. 41 . The filtrate $(3 \mathrm{~mL})$ was transferred into a $100 \mathrm{~mL}$ volumetric flask and made up to volume with Millipore water. Aliquots of these solutions were used in such a way that the concentration of each drug was within the range of the calibration matrix. The diluted solutions were analyzed six times. All the proposed chemometric methods were applied.

\section{Chemometric methods}

Classical least squares (CLS). - This method assumes Beer's law model with the absorbance at each frequency being proportional to the component concentration. In

Table I. Composition of the calibration set

\begin{tabular}{cccccccc}
\hline \multicolumn{3}{c}{ Concentration $\left(\mu \mathrm{g} \mathrm{mL}^{-1}\right)$} & \multicolumn{5}{c}{ Concentration $\left(\mu \mathrm{g} \mathrm{mL}^{-1}\right)$} \\
\hline Mixture & LOS & AML & HYD & Mixture & LOS & AML & HYD \\
\hline 1 & 24 & 3 & 9 & 14 & 24 & 5 & 15 \\
2 & 24 & 1 & 3 & 15 & 40 & 5 & 3 \\
3 & 8 & 1 & 15 & 16 & 40 & 1 & 12 \\
4 & 8 & 5 & 6 & 17 & 8 & 4 & 3 \\
5 & 40 & 2 & 15 & 18 & 32 & 1 & 9 \\
6 & 16 & 5 & 9 & 19 & 8 & 3 & 12 \\
7 & 40 & 3 & 6 & 20 & 24 & 4 & 12 \\
8 & 24 & 2 & 6 & 21 & 32 & 4 & 6 \\
9 & 16 & 2 & 12 & 22 & 32 & 2 & 3 \\
10 & 16 & 4 & 15 & 23 & 16 & 1 & 6 \\
11 & 32 & 5 & 12 & 24 & 8 & 2 & 9 \\
12 & 40 & 4 & 9 & 25 & 16 & 3 & 3 \\
13 & 32 & 3 & 15 & & & & \\
\hline
\end{tabular}

LOS, AML, HYD - losartan potassium, amlodipine besilate, hydrochlorothiazide, respectively. 
D. Nagavalli et al.: Simultaneous spectrophotometric determination of losartan potassium, amlodipine besilate and hydrochlorothiazide in pharmaceuticals by chemometric methods, Acta Pharm. 60 (2010) 141-152.

matrix notation, Beer's law model for $m$ calibration standards containing $l$ chemical components with the spectra of $n$ digitized absorbances is given by:

$$
A=C \times K+E_{\mathrm{A}}
$$

where $A$ is the $m \times n$ matrix of calibration spectra, $C$ is the $m \times l$ matrix of component concentration, $K$ is the $l \times n$ matrix of absorptivity-path length products, and $E_{\mathrm{A}}$ is the $m \times n$ matrix of spectral errors. $K$ then represents the matrix of pure component spectra at unit path length. The classical least squares solution according to Eq. (1) during calibration is:

$$
\hat{K}=\left(C^{\mathrm{T}} C\right)^{-1} C^{\mathrm{T}} \times A
$$

where $\hat{K}$ indicates the least-squares estimation of $K$.

Analysis based on spectrum a, of unknown component concentration (sample):

$$
C_{0}=\left(\hat{K} \hat{K}^{T}\right)^{-1} \hat{K} \times a
$$

where $C_{0}$ is vector of predicted concentration and $\hat{K}^{\mathrm{T}}$ is the transpose of matrix $\hat{K}$.

Multiple linear regressions (MLR). - If absorbance measurements for several solutions containing mixtures of the analytes are made in numbers exceeding the number of mixture components, then the system composed of the absorbance and concentration matrices will be overdimensioned and take the following matrix form:

$$
A=K C
$$

where $A$ is the data absorbance calibration matrix, $K$ is the matrix from which the proportionality constants are calculated from spectra for standard solutions of pure analytes and/or their mixtures, and $C$ is the concentration matrix. The $C$ prediction concentration matrix can be calculated from the following equation:

$$
C=\left(K^{\mathrm{T}} K\right)^{-1} K^{\mathrm{T}}
$$

where $K^{\prime}$ is the transpose of $K$ and $A$ is the absorbance matrix of unknown samples. Matrix $K$ can be obtained in various ways. We calculated $K$ values by $M L R$ of the data for mixtures of analytes of known composition (20).

Principle component regression (PCR). - In the spectral work, the following steps can explain the fundamental concept of PCR. The original data obtained in absorbances $(A)$ and concentrations $(C)$ of analytes were reprocessed by mean-centring as $A_{0}$ and $C_{0}$, respectively. Using the ordinary linear regression:

$$
C=a+b \times A
$$


D. Nagavalli et al.: Simultaneous spectrophotometric determination of losartan potassium, amlodipine besilate and hydrochlorothiazide in pharmaceuticals by chemometric methods, Acta Pharm. 60 (2010) 141-152.

The coefficient $b$ is: $b=P \times q$, where $P$ is the matrix of eigenvectors and $q$ is the C-loadings given by $q=D \times T^{\mathrm{T}} \times A_{0}$. Here, $T^{\mathrm{T}}$ is the transpose of the score matrix $\mathrm{T}$. $\mathrm{D}$ is a diagonal matrix having on components the inverse of the selected eigenvalues. Knowing $b$ one can easily find $a$ by using the formula $a=C_{\text {mean }} \times A^{\mathrm{T}}$ mean $\times b$, where $A^{\mathrm{T}}$ mean represents the transpose of the matrix having the entries of the mean absorbance values, and $C_{\text {mean }}$ is the mean concentration of the calibration set.

Partial least squares (PLS). - In the UV-Vis spectra, the absorbance data $(A)$ and concentration data $(C)$ are mean centered to give the data matrix $A_{0}$ and vector $C_{0}$. The orthogonalized PLS algorithm has the following steps. The loading weight vector $W$ has the following expression:

$$
W=\frac{A_{0}^{\mathrm{T}} C_{0}}{C_{0}^{\mathrm{T}} C_{0}}
$$

The scores and loadings are given by:

$$
\begin{gathered}
t_{1}=\frac{A_{0} W}{A_{0}^{\mathrm{T}} t_{1}} \\
P_{1}=t_{1}^{\mathrm{T}} t_{1} \\
q_{1}=\frac{C_{0}^{\mathrm{T}} t_{1}}{t_{1}^{\mathrm{T}} t_{1}}
\end{gathered}
$$

The matrix and vector of the residuals in $A_{0}$ and $C_{0}$ are:

$$
\begin{aligned}
& A_{1}=A_{0}-t_{1} P_{1}^{\mathrm{T}} \\
& C_{1}=C_{0}-t_{1} q_{1}^{\mathrm{T}}
\end{aligned}
$$

From the general linear equation, the regression coefficients were calculated by:

$$
\begin{gathered}
b=W\left(P^{\mathrm{T}} W\right)^{-1} q \\
a=C_{\text {mean }}-A^{\mathrm{T}} \text { meanb }
\end{gathered}
$$

The built calibration equation is used for the estimation of the compounds in the samples (21). 
D. Nagavalli et al.: Simultaneous spectrophotometric determination of losartan potassium, amlodipine besilate and hydrochlorothiazide in pharmaceuticals by chemometric methods, Acta Pharm. 60 (2010) 141-152.

\section{RESULTS AND DISCUSSION}

A calibration set was randomly prepared as mixtures of LOS, AML and HYD in their possible compositions by applying a multilevel multifactor design (22) (Table I). The UV absorbance data were obtained by measuring the absorbances in the region of 200-400 nm (Fig. 1). From this 230.5-350.4 nm wavelength was selected for construction

Fig. 1. Overlapping spectrum of LOS, AML and HYD.

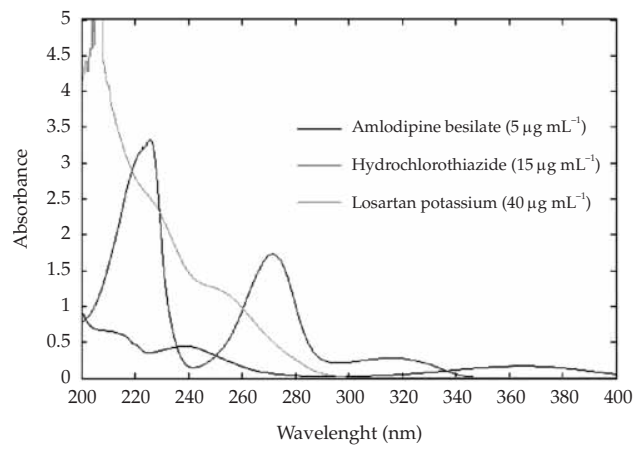

Table II. Statistical parameters of chemometric methods in the calibration set

\begin{tabular}{cclll}
\hline Method & Parameter & LOS & AML & HYD \\
\hline \multirow{3}{*}{ CLS } & RMSECV & 0.1647 & 0.1183 & 0.1823 \\
& RMSEP & 0.1264 & 0.0908 & 0.1110 \\
& $\mathrm{R}$ & 1 & 0.9940 & 0.9990 \\
MLR & RMSECV & 0.2258 & 0.2047 & 0.2583 \\
& RMSEP & 0.2062 & 0.0908 & 0.2328 \\
& $\mathrm{R}$ & 1 & 0.9920 & 0.9980 \\
PCR & RMSEC & 0.1647 & 0.1183 & 0.1823 \\
& RMSECV & 0.1987 & 0.1424 & 0.2134 \\
& RMSEP & 0.1250 & 0.0856 & 0.1120 \\
& $\mathrm{R}$ & 1 & 0.9940 & 0.9990 \\
PLS & RMSEC & 0.1647 & 0.1183 & 0.1823 \\
& RMSECV & 0.1987 & 0.1424 & 0.2134 \\
& RMSEP & 0.1250 & 0.0856 & 0.1120 \\
& $\mathrm{R}$ & 1 & 0.9940 & 0.9990 \\
\hline
\end{tabular}

CLS - classical least squares, MLR - multiple linear regression, PCR - principal component regression. PLS - partial least squares, RMSEP - root mean square error of prediction, RMSECV - root mean square error of cross validation, RMSEC - root mean square error of calibration.

For other acronyms see Table I. 
of the calibration model. The fit model was constructed by using the absorption data matrix corresponding to the concentration data matrix in CLS, MLR, PCR and PLS.

Before constructing the model, pre-processing (23) was carried out to reduce the effect of noise, improve the predictive ability of the model and simplify the model by making the data more normally distributed and the wavelength selection based on the best outcome for reduced error of spectral data. In Table II, $R$ is defined as the correlation coefficient between constituent concentrations and shows the absorbance effects relating to the constituent of interest. Values obtained in the methods close to 1 mean no interference was coming from other constituents in the respective set of calibration mixtures.

The most commonly employed validation criterion is to divide the dataset into two subsets, a calibration set and a validation set. The calibration model is calculated using the calibration set. Then, the root mean square errors of calibration and validation, RMSEC - root mean square error of calibration and RMSECV - root mean square error of cross validation, are calculated by using the calibration model under investigation to predict the samples in the calibration set and validation set, respectively:

$$
\text { RMSEC }=\sqrt{\frac{\left(y-y_{\text {pred }}\right)^{i}\left(y-y_{\text {pred }}\right)}{m-1}}
$$

Selection of the optimum number of factors for PCR and PLS. - For PCR and PLS methods, 25 calibration spectra were used for the selection of the optimum number of factors by using the cross-validation with the leave-out-one technique. This allows modelling of the system with the optimum amount of information and avoidance of over-fitting or under-fitting. The cross-validation procedure consisted of systematically removing one of a group of training samples in turn and using only the remaining ones for the construction of latent variable factors and applied regression. The predicted concentrations were then compared with the actual ones for each of the calibration samples and the root mean square error of prediction (RMSEP) was calculated. The RMSEP was computed in the same manner each time, and then a new factor was added to the PCR and PLS model. The selected model was that with the smallest number of factors such that its

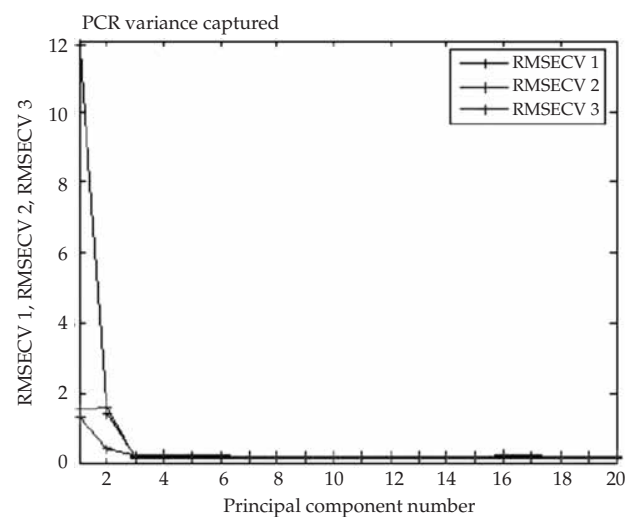

Fig. 2. Representation of RMSECV values generated from calibration by PCR: LOS, AML and HYD. 
Fig. 3. Representation of RMSECV values generated from calibration by PLS: LOS, AML and HYD.

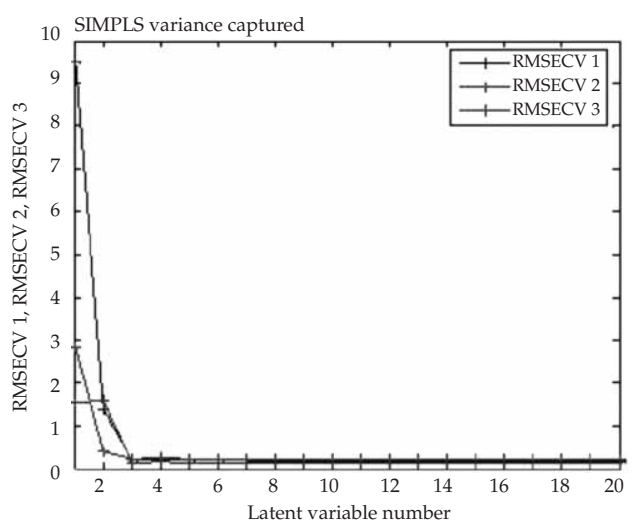

RMSECV values were not significantly greater than that for the model, which yielded the minimum RMSECV. A plot of RMSECV values against the number of components (Figs. 2 and 3) indicates that the latent variable factor 3 was optimum for PCR and PLS selected based on the RMSEC and RMSECV, respectively, for the estimation of the titled drugs. At the selected principal component of PCR and PLS, the concentrations of each sample was then predicted and compared with the known concentration and the RMSEP was calculated:

RMSEC $=\sqrt{\sum_{i=y}^{N} \frac{\left(y_{\text {ipred }}-y_{\text {iref }}\right)^{2}}{N}} \quad \quad$ RMSEC $=\sqrt{\frac{\left(y-y_{\text {pred }}\right)^{i}\left(y-y_{\text {pred }}\right)}{m-1}}$

Table III. Composition of synthetic mixtures (formulation) and recovery set

\begin{tabular}{rcrcccccc}
\hline \multicolumn{2}{c}{ Synthetic formulation $\left.(\mu \mathrm{g} \mathrm{mL})^{-1}\right)^{\mathrm{a}}$} & \multicolumn{3}{c}{ Formulation $\left.(\mu \mathrm{g} \mathrm{mL})^{-1}\right)^{\mathrm{b}}$} & \multicolumn{3}{c}{ Recovery $\left.(\mu \mathrm{g} \mathrm{mL})^{-1}\right)^{\mathrm{c}}$} \\
\hline \multicolumn{1}{c}{ LOS } & AML & HYD & LOS & AML & HYD & LOS & AML & HYD \\
\hline 24.8 & 3.6 & 10.8 & 30 & 3 & 7.5 & 3 & 0.45 & 0.75 \\
24.8 & 1.2 & 3.6 & 30 & 3 & 7.5 & 3 & 0.45 & 0.75 \\
9.6 & 1.2 & 18.0 & 30 & 3 & 7.5 & 3 & 0.45 & 0.75 \\
9.6 & 6.0 & 7.2 & 30 & 3 & 7.5 & 6 & 0.90 & 1.50 \\
48.0 & 2.4 & 18.0 & 30 & 3 & 7.5 & 6 & 0.90 & 1.50 \\
19.2 & 6.0 & 10.8 & 30 & 3 & 7.5 & 6 & 0.90 & 1.50 \\
48.0 & 3.6 & 7.2 & 30 & 3 & 7.5 & 9 & 1.35 & 2.25 \\
28.8 & 2.4 & 7.2 & 30 & 3 & 7.5 & 9 & 1.35 & 2.25 \\
19.2 & 2.4 & 14.4 & 30 & 3 & 7.5 & 9 & 1.35 & 2.25 \\
\hline
\end{tabular}

a Synthetic mixture of LOS, AML and HYD (standards).

b Pharmaceutical formulation, tablet.

c Recovery - standard addition to pharmaceutical formulation..

For other acronyms see Table I. 
D. Nagavalli et al.: Simultaneous spectrophotometric determination of losartan potassium, amlodipine besilate and hydrochlorothiazide in pharmaceuticals by chemometric methods, Acta Pharm. 60 (2010) 141-152.

Table IV. Prediction results for losartan, amlodipine and hydrochlorothiazide from the synthetic validation samples by different chemometric methods

\begin{tabular}{ccrrrrrrr}
\hline \multirow{2}{*}{ Component } & \multicolumn{2}{c}{ CLS } & \multicolumn{2}{c}{ MLR } & \multicolumn{2}{c}{ PCR } & \multicolumn{2}{c}{ PLS } \\
\cline { 2 - 9 } & \multicolumn{2}{c}{ Mean \pm SD $^{\mathrm{a}}$} & \multicolumn{2}{c}{ Mean \pm SD $^{\mathrm{a}}$} & \multicolumn{2}{c}{ Mean \pm SD $^{\mathrm{a}}$} & \multicolumn{2}{c}{ Mean \pm SD $^{\mathrm{a}}$} \\
\hline LOS & 100.6 & 0.9 & 100.4 & 1.2 & 100.6 & 0.9 & 100.6 & 0.9 \\
AML & 100.0 & 1.6 & 100.6 & 0.7 & 100.0 & 0.5 & 100.0 & 0.5 \\
HYD & 100.9 & 0.6 & 99.7 & 0.9 & 100.9 & 0.7 & 100.9 & 0.7 \\
\hline
\end{tabular}

a Nine determinations.

For acronyms see Table I and II.

In order to test the proposed techniques, the validation set of synthetic mixtures (from standards) containing the three drugs (Table III) in variable ratios was carried out; the results are given in Table IV. The maximum values of the mean percent errors corresponding to CLS, MLR, and PCR and PLS for the same mixtures were completely acceptable because of their very small numerical values (below 0.2). Results of tablet analyses are shown in Table V.

\section{Recovery and precision studies}

To check the validity of the proposed methods, recovery studies were carried out by addition of the standard to the preanalyzed formulation. Results of recovery studies were found to be from $99.3 \pm 0.3$ to $101.3 \pm 0.6 \%$ (Table VI). Good precision of the method was indicated by RSD ranging $0.3-1.4 \%$.

Table V. Prediction results for losartan, amlodipine and hydrochlorothiazide in formulation samples by different chemometric methods

\begin{tabular}{cclll}
\hline Method & Parameter $^{\mathrm{a}}$ & LOS & AML & HYD \\
\hline \multirow{2}{*}{ CLS } & Mean (\%) & 100.02 & 100.39 & 101.28 \\
& RSD (\%) & 0.034 & 0.720 & 0.131 \\
MLR & Mean (\%) & 100.27 & 98.92 & 101.52 \\
& RSD (\%) & 0.078 & 1.683 & 1.192 \\
PCR & Mean (\%) & 100.01 & 100.36 & 101.32 \\
& RSD (\%) & 0.033 & 0.705 & 0.128 \\
PLS & Mean (\%) & 100.01 & 100.36 & 101.32 \\
& RSD (\%) & 0.033 & 0.705 & 0.128 \\
\hline
\end{tabular}

\footnotetext{
a Nine determinations.
} 
D. Nagavalli et al.: Simultaneous spectrophotometric determination of losartan potassium, amlodipine besilate and hydrochlorothiazide in pharmaceuticals by chemometric methods, Acta Pharm. 60 (2010) 141-152.

Table VI. Recovery studies of LOS, AML and HYD in pharmaceutical formulations ${ }^{a}$

\begin{tabular}{|c|c|c|c|c|c|c|c|c|c|}
\hline \multirow[b]{2}{*}{ Method } & \multicolumn{3}{|c|}{ LOS } & \multicolumn{3}{|c|}{ AML } & \multicolumn{3}{|c|}{ HYD } \\
\hline & $\begin{array}{c}\text { Added } \\
\left(\mu \mathrm{g} \mathrm{mL} L^{-1}\right)\end{array}$ & $\begin{array}{c}\text { Found } \\
\left(\mu \mathrm{g} \mathrm{mL} L^{-1}\right)\end{array}$ & $\begin{array}{l}\text { Recovery } \\
(\%)^{\mathrm{b}}\end{array}$ & $\begin{array}{c}\text { Added } \\
\left(\mu \mathrm{g} \mathrm{mL}^{-1}\right)\end{array}$ & $\begin{array}{c}\text { Found } \\
\left(\mu \mathrm{g} \mathrm{mL}^{-1}\right)\end{array}$ & $\begin{array}{c}{ }^{*} \text { Recovery } \\
(\%)^{b}\end{array}$ & $\begin{array}{c}\text { Added } \\
\left(\mu \mathrm{g} \mathrm{mL} L^{-1}\right)\end{array}$ & $\begin{array}{c}\text { Found } \\
\left(\mu \mathrm{g} \mathrm{mL}^{-1}\right)\end{array}$ & $\begin{array}{c}* \text { Recovery } \\
(\%)^{b}\end{array}$ \\
\hline \multirow{3}{*}{ CLS } & 3 & 33.1 & 100.4 & 0.5 & 3.4 & 99.8 & 0.8 & 8.4 & 101.6 \\
\hline & 6 & 36.0 & 100.0 & 0.9 & 3.9 & 99.2 & 1.5 & 9.1 & 100.6 \\
\hline & 9 & 39.0 & 100.1 & 1.4 & 4.3 & 99.4 & 2.3 & 9.9 & 101.6 \\
\hline Mean & & & 100.1 & & & 99.5 & & & 101.3 \\
\hline S.D & & & \pm 0.2 & & & \pm 0.3 & & & \pm 0.6 \\
\hline \multirow{3}{*}{ MLR } & 3 & 33.0 & 100.1 & 0.5 & 3.5 & 101.3 & 0.8 & 8.4 & 102.2 \\
\hline & 6 & 35.7 & 99.3 & 0.9 & 3.9 & 99.9 & 1.5 & 9.1 & 100.6 \\
\hline & 9 & 39.1 & 100.2 & 1.4 & 4.4 & 100.5 & 2.3 & 9.8 & 100.3 \\
\hline Mean & & & 99.9 & & & 100.5 & & & 101.0 \\
\hline S.D & & & \pm 0.7 & & & \pm 1.0 & & & \pm 1.4 \\
\hline \multirow{3}{*}{ PCR } & 3 & 33.1 & 100.3 & 0.5 & 3.4 & 99.8 & 0.8 & 8.4 & 101.7 \\
\hline & 6 & 36.0 & 100.0 & 0.9 & 3.9 & 99.0 & 1.5 & 9.1 & 100.6 \\
\hline & 9 & 39.0 & 100.0 & 1.4 & 4.3 & 99.2 & 2.3 & 9.9 & 101.6 \\
\hline Mean & & & 100.1 & & & 99.3 & & & 101.3 \\
\hline S.D & & & \pm 0.2 & & & \pm 0.4 & & & \pm 0.6 \\
\hline \multirow{3}{*}{ PLS } & 3 & 33.1 & 100.3 & 0.5 & 3.4 & 99.7 & 0.8 & 8.4 & 101.7 \\
\hline & 6 & 36.0 & 100.0 & 0.9 & 3.9 & 99.0 & 1.5 & 9.1 & 100.6 \\
\hline & 9 & 39.0 & 100.0 & 1.4 & 4.3 & 99.2 & 2.3 & 9.9 & 101.6 \\
\hline Mean & & & 100.1 & & & 99.3 & & & 101.3 \\
\hline S.D & & & \pm 0.2 & & & \pm 0.4 & & & \pm 0.6 \\
\hline
\end{tabular}

a Additions to $30 \mu \mathrm{g} \mathrm{mL}^{-1} \mathrm{LOS}, 3 \mu \mathrm{g} \mathrm{mL}^{-1} \mathrm{AML}$ and $7.5 \mu \mathrm{g} \mathrm{mL}-1$ HYD in the formulation.

b Nine determinations.

\section{CONCLUSIONS}

Based on the results obtained in this work, the UV spectrophotometric method for simultaneous determination of losartan potassium, amlodipine besilate and hydrochlorothiazide in mixtures by multivariate calibration of synthetic and pharmaceutical samples is applicable. PLS and PCR using a calibration matrix constructed with absorption spectra were successfully applied to simultaneous analysis of these drugs in synthetic and pharmaceutical mixtures.

Acknowledgements. - One of the authors, Mrs. D. Nagavalli, gratefully acknowledges the support from the management of Adhiparasakthi Medical and Charitable Trust, Melmaruvathur, in providing necessary facilities to carry out this research work. Orchid (Chemicals \& Pharmaceuticals, Ltd, R\&D division, Chennai, and Prof Dr. A. K. Mishra, IIT, Chennai) are kindly acknowledged for allowing to use their facilities. 
D. Nagavalli et al.: Simultaneous spectrophotometric determination of losartan potassium, amlodipine besilate and hydrochlorothiazide in pharmaceuticals by chemometric methods, Acta Pharm. 60 (2010) 141-152.

\section{REFERENCES}

1. Merck Index, $14^{\text {th }}$ ed., Merck and Co. Inc., White House Station 2003.

2. N. Erk, Analysis of binary mixtures of losartan potassium and hydrochlorothiazide by using high performance liquid chromatography, ratio derivative spectrophotometric and compensation technique, J. Pharm. Biomed. Anal. 24 (2001) 603-611.

3. D. L. Hertzog, J. F. McCafferty, X. Fang, R. J. Tyrrell, R. A. Reed, Development and validation of a stability-indicating HPLC method for the simultaneous determination of losartan potassium, hydrochlorothiazide, and their degradation products, J. Pharm. Biomed. Anal. 30 (2002) 747-760.

4. M. Polinko, K. Riffel, S. Hengchang and L. O. Man-Wai, Simultaneous determination of losartan and EXP3174 in human plasma and urine utilizing liquid chromatography/tandem mass spectrometry, J. Pharm. Biomed. Anal. 33 (2003) 73-84; DOI:10.1016/S0731-7085(03)00348-0.

5. R. K. Barman, M. A. Islam, M. Ahmed, M. I. Ibnewahed, R. Islam, A. Khan, M. B. Hossain and B. M. Rahman, Simultaneous high-performance liquid chromatographic determination of atenolol and amlodipine in pharmaceutical-dosage form, Pak. J. Pharm. Sci. 20 (2007) 274-279.

6. M. D. Malesuik, S. G. Cardoso, L. Bajerski and F. A. Lanzanova, Determination of amlodipine in pharmaceutical dosage forms by liquid chromatography and ultraviolet spectrophotometry, J. AOAC Int. 89 (2006) 359-364.

7. F. Belal, I. A. Al-Zaagi, E. A. Gadkariem and M. A. Abounassif, A stability-indicating LC method for the simultaneous determination of ramipril and hydrochlorothiazide in dosage forms, J. Pharm. Biomed. Anal. 24 (2001) 335-342.

8. O. C. Lastra, I. G. Lemus, H. J. Sánchez and R. F. Pérez, Development and validation of a UV derivative spectrophotometric determination of losartan potassium in tablets, J. Pharm. Biomed. Anal. 33 (2003) 175-180.

9. M. C. Ferro, P. M. Castellano and T. S. Kaufman, Simultaneous determination of amiloride hydrochloride and hydrochlorothiazide in synthetic samples and pharmaceutical formulations by multivariate analysis of spectrophotometric data, J. Pharm. Biomed. Anal. 30 (2002) 1121-1131.

10. M. A. Obando, J. M. Estela and V. Cerda, Simultaneous determination of hydrochlorothiazide and losartan potassium in tablets by high-performance low-pressure chromatography using a multi-syringe burette coupled to a monolithic column, Anal. Bioanal. Chem. 391 (2008) 2349-2356.

11. S. A. Shah, I. S. Rathod, B. N. Suhagia, S. S. Savale and J. B. Patel, Simultaneous determination of losartan and hydrochlorothiazide in combined dosage forms by first-derivative spectroscopy and high-performance thin-layer chromatography, J. AOAC Int. 84 (2001) 1715-1723.

12. R. B. Kakde, V. H. Kotak and D. L. Kale, High performance thin layer chromatographic method for simultaneous estimation of amlodipine besilate and bisoprolol fumarate in pharmaceutical preparations, Pharma Rev. Dec-2008, 168-170.

13. Y. Ma, F. Qin, X. Sun, X. Lu and F. Li, Determination and pharmacokinetic study of amlodipine in human plasma by ultra performance liquid chromatography-electrospray ionization mass spectrometry, J. Pharm. Biomed. Anal. 43 (2007) 1540-1545.

14. R. Kramer, Chemometric Techniques in Quantitative Analysis, Marcel Dekker, New York 1998.

15. H. Martens and T. Naes, Multivariate Calibration, Wiley, New York 1989.

16. E. Dinç and A. Ozdemir, Linear regression analysis and its application to multivariate chromatographic calibration for the quantitative analysis of two-component mixtures, Farmaco 60 (2005) 591-597.

17. R. Brereton, Chemometrics. Data Analysis for the Laboratory and Chemical Plant, Wiley, Chichester 2003.

18. R. Bro, Håndbog i Multivariabel Kalibrering, Jordbrugsforlaget, Copenhagen, 1996. 
D. Nagavalli et al.: Simultaneous spectrophotometric determination of losartan potassium, amlodipine besilate and hydrochlorothiazide in pharmaceuticals by chemometric methods, Acta Pharm. 60 (2010) 141-152.

19. E. Dinç and D. Baleanu, Spectrophotometric quantitative determination of cilazapril and hydrochlorothiazide in tablets by chemometric methods, J. Pharm. Biomed. Anal. 30 (2002) 715-723.

20. Nagaraj, K. Vipul and M. Rajshree, Simultaneous quantitative resolution of atorvastatin calcium and fenofibrate in pharmaceutical preparation by using derivative ratio spectrophotometry and chemometric calibrations, Anal. Sci. 23 (2007) 445-451; DOI: 10.2116/analsci.23.445.

21. I. M. Palabiyik, E. Dinç and F. Onur, Simultaneous spectrophotometric determination of pseudoephedrine hydrochloride and ibuprofen in a pharmaceutical preparation using ratio spectra derivative spectrophotometry and multivariate calibration techniques, J. Pharm. Biomed. Anal. 34 (2004) 473-483.

22. R. G. Brereton, Multilevel multifactor designs for multivariate calibration, Analyst 122 (1997) 1521-1529.

23. G. R. Flåten and A. D. Walmsley, Using design of experiments to select optimum calibration model parameters, Analyst 128 (2003) 935-943; DOI: 10.1039/b301555f.

\section{$S A \check{Z} E T A K$}

\section{Istodobno spektrofotometrijsko određivanje losartan kalija, amlodipin besilata i hidroklorotiazida $\mathbf{u}$ farmaceutskim pripravcima kemometrijskom metodom}

D. NAGAVALLI, V. VAIDHYALINGAM, A. SANTHA, A. S. K.SANKAR i O. DIVYA

U radu su opisane četiri spektrofotometrijske metode za istodobno određivanje losartan kalija, amlodipin besilata i hidroklorotiazida u sirovinama i farmaceutskim pripravcima. Podaci koji su se preklapali kvantitativno su razlučeni kemometrijskim metodama, klasičnom metodom najmanjih kvadrata (CLS), multiplom linearnom regresijom (MLR), regresijom glavnih komponenata (PCR) te metodom parcijalnih najmanjih kvadrata (PLS). Kalibracije su provedene koristeći podatke o ovisnosti apsorpcije o koncentracijama, mjereći spektre nultog reda u rasponu 230,5-350,4 $\mathrm{nm}(\Delta \lambda=0,1 \mathrm{~nm})$. Linearnost za losartan kalij bila je $8-40$, za amlodipin besilat $1-5$, a za hidroklorotiazid 3-15 $\mu \mathrm{g} \mathrm{mL}-1$. Valjanost predloženih metoda uspješno je potvrđena analizom navedenih lijekova u različitim pripremljenim smjesama i tabletama.

Ključne riječi: losartan, amlodipin besilat, hidroklorotiazid, spektrofotometrija, kemometrija

Department of Pharmaceutical Analysis, Adhiparasakthi College of Pharmacy, Melmaruvathur-603319, Kanchipuram District, Tamil Nadu, India

Madras Medical College, Chennai-600003, India

C. L. Baid Metha College of Pharmacy, Chennai-600 096, Tamil Nadu, India

IIT, Chennai-600036, Tamil Nadu, India 